UDC $81.16,81.139$

DOI: $10.17223 / 24109266 / 13 / 2$

\title{
LINGUO-COGNITIVE NATURE OF IRONIC UTTERANCES IN THE GERMAN NEWS MEDIA
}

\author{
I.A. Kotiurova
}

\begin{abstract}
The study is devoted to the linguo-cognitive nature of ironic utterances. The use of the linguistic cognitive approach to ironic utterances makes it possible to interpret such examples of ironic communication that formerly remained inaccessible to explanation from the standpoint of structural linguistics. The purpose of this work is to study the linguo-cognitive mechanisms underlying the ironic utterances in the texts of German newspapers and magazines. By analyzing more than 1,000 examples of ironic utterances taken in contemporary German journalism, the study defined, firstly, the type of information necessary for the ironic meaning actualization, and second, the scheme of cognitive calculations, leading to the interpretation of utterance as ironic. As a result, 4 main types of information frames (frame-concepts, language frames, frame-scenarios and frame-settings), a general linguo-cognitive model of the ironic utterance and 8 models of its implementation in a journalistic text were described. The obtained data reveals that language can perform a dual role in the formation of ironic meaning. On the one hand, language meanings serve as a verbal transmission of irony-based frames. On the other hand, language frames can be a direct material for the creation of linguistic irony.
\end{abstract}

Keywords: irony; cognitive approach; linguistic cognitive model; German journalism.

\section{Introduction}

This linguistic cognitive study is devoted to the phenomenon of irony which arises in communication as an intentional meaning of the utterance and has various forms of representation in speech.

The background of the term 'irony' from ancient times to modern linguistic theories is very diverse. Over more than two thousand years of research development, its notion changed and was replenished significantly, with not only philologists and philosophers but also literary scholars, cultural specialists, psychologists, psychoanalysts among its researchers. Different points of view on irony are represented, in particular, by $\mathrm{H}$. Weinrich, M. Clyne, H. Löffler, W.-D. Stempel, U. Gießmann, U. Oomen, D.J. Amante, H. Havekate, N. Groeben, I. Rosengren, D. Sperber and D. Wilson, R.J. Kreuz and S. Glücksberg, R.W. Gibbs and J. O'Brien, M. Hartung and others (see for more detail [1]).

Speaking of irony from the linguistic points of view, one must take into account that this term is treated ambiguously. In the Dictionary of Linguistic Terms by O.S. Akhmanova, we can find the following definition: 
"irony is a path consisting of the use of a word in the sense of literal reverse aimed to a subtle or concealed mockery; a mockery which is deliberately expressed in the form of a positive characteristic or praise. For example: "Just look at that Samson!" (about a weak, frail person)" [2: 185]. In many respects, this definition is contradicted by the point of view on the ironic utterance, supported in the Linguistic Dictionary by T. Lewandowski: "a form of indirect evaluative statement, wherein there is tension between the literal meaning of the utterance and its intentional meaning" [3: 497].

Thus, irony is considered, on the one hand, as a figure of speech based on the opposite of explicit and implied meanings, and, on the other hand, more broadly, as an expression of the modal relation in which various means of verbal and semantic levels participate.

If we treat irony as an indirect expression of mockingly critical attitude, then the potential infinity of the ways for its realization, and not the relation to one or several specific figures of speech, becomes obvious. The relationship can be realized both with the special rhetorical figures and neutral language structures, but conditioned contextually or situationally. This is because irony is based on a certain cognitive model, a mechanism of consciousness that allows, one, on the one hand, to convey and, on the other hand, to understand the mocking-critical attitude of the speaker, and this model can be described. This corresponds to the basic idea of the modern cognitive approach to the language, which consists in the purposeful reconstruction of cognitive structures, according to the external language form and language behavior (A.E. Kibrik) [4: 126-139].

Cognitive linguistics had a strong influence on the study of all the aspects of communication, expanding the possibilities of linguistics in interpreting utterances; this fully applies to the phenomenon of irony expressed through language. The use of the linguistic cognitive approach to ironic utterances makes it possible to interpret such examples of ironic communication that formerly remained inaccessible to explanation from the standpoint of structural linguistics. In this sense, the study of irony in the linguocognitive aspect turns out to be relevant and promising. In addition, the relevance of the study is in the fact that it 'tests' the theory of cognitive linguistics with reference to the study of ironic meanings.

Theoretical background includes the works on the cognitive nature of communication by A.E. Kibrik, V.Z. Demyankova, E.S. Kubryakova, O. Yokoyamy, and T.A. van Dijk, the theory of conceptual (cognitive) metaphor by J. Lakoff and M. Johnson, pragmalinguistic studies of the ironic meaning by E. Lapp and M. Hartung, and psycholinguistic studies of the irony by S. Freud, N. Gröben, and R.V. Gibbs.

The postulate on initial cognitive motivation allows advancing the thesis about the presence of fairly rigid logic in the ironic utterance. Identification and description of this logic, which establishes the actual relations 
between linguistic forms and cognitive structures of the ironic speech, is the purpose of this study.

\section{Materials}

The material for the study was examples of ironic statements collected from more than two thousand political articles in modern German newspapers and magazines. The body of the study was composed of more than 1,000 examples of ironic utterances from articles of the newspapers Tageszeitung, Die Welt, Schwäbisches Tagblatt, Jungle World, Frankfurter Allgemeine Zeitung and Der Spiegel magazine for the period 2004-2018.

\section{Methods}

In 1921, the thought of the cognitive motivation of linguistic form was first formulated by Edward Sapir: "From the point of view of the language, thinking can be defined as the highest latent or potential content of speech; as such content that can be achieved by interpreting each element of the speech stream as maximally endowed conceptual significance" [36: 193]. This idea forms the methodological basis of the study.

Thus, linguo-cognitive analysis was chosen as the main method for the study of ironic utterances. Since the key idea of cognitive linguistics is that language is a reflection of consciousness, we start from the language form of each specific example of irony in order to draw conclusions about what is happening in the cognitive structures of consciousness. The linguistic cognitive approach assumes the analysis of verbal ironic utterance and on its basis the hypothesis about what is happening in the person's consciousness when the ironic utterance is perceived, what cognitive structures turn out to be activated, and how their excitation occurs.

The scheme of the study was as follows. First, a body of examples of ironic utterances was collected by continuous sampling from political articles in modern German newspapers and magazines. Then, in order to achieve the above-described goal, the examples were subjected to the following analysis and generalization:

1. Language structure was defined that focused on the ironic meaning, and the cognitive structure behind it.

2. Type of context necessary to implement the ironic meaning of the utterance was determined.

3. The role of language in the ironic utterance as of a pointer to certain frames for constructing the ironic meaning and as of an immediate material to create linguistic irony was differentiated.

4. There was a discord between the literal meaning and the significant background, which is the basis of the general linguistic cognitive model of irony. 
5. Display of an indication to the appropriate background knowledge at the linguistic level was determined.

6. Based on the analysis and the corresponding grouping, the thematic classification of linguo-cognitive structures found in German politicaloriented journalistic articles was further compiled.

7. General linguistic cognitive model of neutral and ironic utterance (the procedures that make it possible to recognize the meaning of the neutral and ironic utterance) was described.

8. Relying on the linguistic expression of ironic meaning in the studied examples, the options for implementing a general cognitive model of ironic utterance in the German newspaper text were revealed and described.

9. Finally, a classification of linguo-cognitive mechanisms which are the basis of ironic utterances in the texts of German political newspapers and magazines was given.

\section{Results}

In the course of the study, two key questions were answered:

1) what cognitive structures find their linguistic expression in ironic utterances of German articles on political topics and 2) what linguocognitive mechanisms are at the heart of ironic utterances.

Speaking of cognitive structures that find their expression in the language, the term "frame" is used.

Despite the diversity of the 'frame' description in the scientific literature, most linguists treat it as "a data structure for representing stereotyped situations, a unit of knowledge organized around a concept" [6:187].

C. Fillmore calls the frames "a special organization of knowledge that constitutes the necessary precondition for our ability to understand closely related words" [7: 54]. The scientist compares the frame with modular furniture, where individual frames can be combined into larger designs.

T.A. van Dijk defines the frame as 'a unit of knowledge organized around a certain concept, containing the basic, typical and potentially possible information that is associated with a particular concept" [8: 16].

Common thing in all interpretations is the frame purpose: the organization of knowledge in order to maintain and activate it in the appropriate context. Thus, speaking about frames, it should be understood they are not just conceptual knowledge but a data structure, the organization of this knowledge.

This is what determines the difference between "frame" and "concept". The frame structures the conceptual knowledge, filling out its scheme in accordance with the current situation. In addition, it organizes not only the concepts but also scripts and other types of knowledge which will be discussed below. 
The features of one or another phenomenon are represented in the frame by a hierarchical structure, where the main (i.e. typical) and potentially possible information about this phenomenon is located at different levels (a detailed hierarchical structure is described, for example, in the work of M. Minsky 'Frames for the representation of knowledge' [9: 189]). The top of the frame is its name; the upper levels are fixed and correspond to things that are always fair in relation to the object or situation. For example, the "cube" frame in vertex nodes will contain the following information: a regular polyhedron, each facet a square; these features are inherent to any cube. The components of the frame structure below the vertex nodes are usually called terminals, or slots. Slots contain the specific knowledge about the frame attributes. These may be features optional but typical for a given object or situation, as well as atypical but potentially possible, information about them being obtained as a result of some subjective experience. The lower slots of the 'cube' frame can contain information about the color, size, visible facets, etc., being filled in according to the situation.

Hierarchy is of great importance for the success of ironic utterance. The fact on which nodes of the frame structure (vertex or lower level) the irony is focused is a very important point.

So, for example, in an ironic article about the dismissal of TV presenter Eva Herman and her replacement with Reinhold Beckmann, the wellknown columnist Hans Zippert writes: Die Verantwortlichen glauben möglicherweise, es fällt vielen Zuschauern gar nicht auf, Beckmann klingt ja zunächst so ähnlich wie Herman. / Herman-Ersatz Beckmann vor großer Prüfung // welt-online vom 13.09.2007 (Eva Herman was hosting the news programme on the ARD channel for 17 years. In 2006, she was dismissed due to the publication of her book 'Das Eva-Prinzip' in which she expressed her political views on family issues and the distribution of the social roles between men and women in the family. The book caused a wave of disputes in the media).

The journalist expresses his critical attitude towards those who are behind this replacement (die Verantwortlichen), attributing to them the assumption that the audience will not notice the substitution of TV presenter because of the similar sounding of their surnames - Hermann and Beckman. The irony is in the assertion of the absurd opinion: you can confuse the TV presenters of different genders (that is, their visual image) because of the similar sounding of their surnames. The ironic meaning arises from the apparent contradiction in the framing of causal relationship of the frames 'to confuse the visual image' and 'to have a similar sound', and the obviousness of such contradiction is explained by the collision of vertex slots of the given frames: 'sight' and 'hearing', respectively.

When vertex nodes come into conflict, as in this example, one can rely on the communicative success of the utterance, that is, be sure that all read- 
ers will recognize the ironic meaning. If for the understanding of irony the activation of lower level slots is necessary, the irony turns out to be less obvious. The lower the level of the activated slots (at the lower level, the slots are potentially free and filled subjectively), the more difficult the decoding process of the implied ironic sense and the less likely the success.

This can be seen in the example of the scandal that erupted in the German press after the publication of the article 'Onkels Obama Hütte'. It was accompanied by a big photo of the White House, which was one of the sides of the ironic juxtaposition: Hütte in the title of the article contrasts with the 'palace' in the photograph. The media and readers got the allusion to the famous novel by American writer Harriet Beecher Stowe 'Uncle Tom's Cabin' and accused the journalists of taz newspaper of racism, actualizing only the comparison of the frames 'Uncle Tom' and 'Barack Obama' by the black complexion. (It should be explained that 'black skin' is the vertex slot not only in the frame 'Uncle Tom' but also in the frame 'Barack Obama', since the main accent of the pre-election struggle of Barack Obama, although not officially announced, was connected with his African American roots. The color of Barack Obama's skin was a constant and very important topic of discussion both in private conversations and in the media. In particular, all the local and foreign media discussed that a black president can come to power in the US, which indicates the high development of democracy in the country.) Indirect indication of the complexion itself is perceived as a manifestation of racist attitudes. In addition, the readers regarded the article as an insult to Barack Obama, since comparing him with a well-known literary character means transferring to him another frame slot 'Uncle Tom', typical for the picture of the world of Americans - a slave, a traitor.

Being forced to prove their loyalty to the black population of America, journalists argued that no sane person of the $21^{\text {st }}$ century could come up with the idea of comparing the situation of black people in the $19^{\text {th }}$ century and today. Journalists also referred to a large photo of the White House under the heading Onkels Obama Hütte, which was supposed to emphasize the contrast and, as a consequence, the irony of the title.

Thus, the readers actualized the association of 'black' and 'slave', and the journalists counted on comparing the frames 'hut' - 'palace'; the ironic joke was unsuccessful. This example clearly demonstrates one of the potential causes of communicative failure - focusing ironic contrast on the lower, rather than the vertex, slot in a newspaper text with a large number of addressees of the utterance. Thus, frames serve the organization of knowledge for storing and activating it in an appropriate context.

Scientific literature is abundant in different typologies of frames. Marvin Minsky, the founder of the frame theory, divided them into different types, pointing to the presence in the human mind of frames for realizing 
visual images (frames of visual images), understanding words (semantic frames), reasoning, actions (frame-scenarios), and narrative [10: 189].

Charles Fillmore, who first used the term 'frame' in a linguistic description, spoke of grammatical frames containing lexical, grammatical, syntactic and semantic information (See http://www.krugosvet.ru/articles/90/ 1009010/1009010a1.htm).

In the current practice of computer linguistics, frames are divided into two types according to the kind of knowledge contained in them: declarative (to which a person has an informed access and which can be expressed by the language) and procedural (containing knowledge sequence of action for some procedure, for example, riding a bicycle). This division of declarative and procedural knowledge corresponds to the different types of knowledge available to a person - the so-called knowledge THAT (declarative, such as knowing the postal address of a certain X), on the one hand, and knowledge HOW (procedural, such as knowledge which allows finding the apartment of this $\mathrm{X}$, even without knowing their formal address) on the other (http://www.krugosvet.ru/ articles/92/1009220/1009220a1.htm). In cognition, frames are likewise divided into static (actual frames) and dynamic (frame-scenarios).

All these typologies turned out to be insufficient for the analysis of frames activated in ironic utterances in modern journalism, since they ignore the social factor, very important in journalism - the connection with the life and activity of the native speaker within the society and with the continuity of the rules and attitudes of the society in which they live. It should be noted that V.V. Krasnykh, speaking of linguistic and phenomenological cognitive structures that form the cognitive basis of a particular linguistic personality, pays attention to the importance of social (public and individual) attitudes but does not consider them as cognitive structures of a particular type [11:43].

In this paper, the base for describing the frames upon which the ironic meaning is built is the four key types of knowledge identified by T.A. Van Dijk [12]. He names the following types of knowledge stored in the memory of a person: 1) representations of objects and personalities; 2) scenarios of individual episodes; 3 ) knowledge of the units, categories and rules of the language, discourse and communication, and 4) evaluative notions of social phenomena, structures or problems for which the author uses the classical term 'settings'.

With the support of this typology of knowledge, the work divides the frames into the following basic types:

1. Frames-concepts are data structures storing static extralinguistic knowledge about living and inanimate nature, real and imaginary worlds. Frames-concepts are very diverse and can be typed thematically. In the body of examples of ironic utterances taken from political articles, such frames are classified according to the following main types of extralinguistic knowledge: 
- existential and common frames - representations of knowledge concerning everyday life (Der städtische Bauamtsleiter Joachim Russ ließ den kleinen Funken Hoffnung auf einen Standortwechsel der Lichtsäule am Dienstagabend im Technischen Ausschuss des Gemeinderats sogleich wieder verglühen.);

- existential-political frames - representations of knowledge about the structure of the world of politics and its structures (Ist die SPD nicht schon 2005 der CDU beigetreten?);

- frames-personalities - representations of knowledge about personalities (Die Menschheit hat Schlimmeres überstanden als die Blockflöte, $\langle\ldots\rangle$, zum Beispiel diesen grinsenden Geiger, der mit seinem süßlichen Gefiedel eine Schleimspur durch die Fernsehshows zieht - richtig, André Rieu heißt er.);

- culturological frames - representations of knowledge about the material and spiritual culture of a certain people and of all mankind (Was sie dabei auf dem Bergfriedhof wollten, wird man wohl nie erfahren - vielleicht sollte ja zu später Stunde am Grab Max Webers ein besonders charismatisches, pardon, legendäres [Pokémon-] Exemplar erscheinen.);

- 'financial' frames - representations of knowledge generally associated with financial management both at the global level and at the level of the family budget (Die Probleme sind allgegenwärtig: Fluglärm, AKWs, Schweiz- ... - Pardon: Schwarzgeld.);

- 'medical' frames - representations of knowledge associated with diseases and all possible ways of treating them ( $\mathrm{Na}$ gut, heute gibt es auch für jedes bizarre Produkt der Pharmaindustrie einen Arzt, der sich die passende Krankheit dazu ausdenkt.).

2. Language frames are data structures about the language code, i.e. vocabulary, grammar, stylistics, and phonetics of a particular language. In the group of language frames, the following types of frames can be selected, respectively:

- lexical (Dass der Weg der musikalischen Früherziehung steinig ist und voller Schlaglöcher, davon können Generationen von Eltern sozusagen ein Lied singen.);

- morphological (Jetzt kommt es darauf an, mit einer klaren Machtalternative anzutreten. Die 'Steine', -meier und -brück, wurden für Agenda und auch das ungenaue GroKo-Angebot abgestraft.);

- stylistic (Am Anfang wollte Brandt 'mehr Demokratie wagen', am Ende Schmidt mehr Volkswagen);

- syntactic (Für William und Kate bleibt kein Altstadt-Pflasterstein unpoliert, kein Gully unversiegelt, kein Neckar ungesperrt.);

- phonetic (Jetzt trommelt er [Jean-Marc Puissesseau] mit den Fingern auf die Platte seines leeren Schreibtisches und sagt auf Deutsch, es sei 'sähr traurik'.). 
3. Frame-scenarios are complex structures that contain knowledge of the standard course of events in a typical situation (for example, the purchase of goods via the Internet, elections in Germany, going to the cinema with friends, etc.), as well as knowledge about the development of unique events for example, the tragedy of 11.09.2001, the 'diesel' scandal of Volkswagen, a sensational breakthrough in the Bundestag of the 'Alternative for Germany' party in the 2017 elections, etc.). Accordingly, the following types of frames are distinguished:

- frame-scenarios of typical situations (Was man nicht alles für seine Gäste tut. Die Bude sieht aus wie Sodom und Gomorrha, aber sobald die Schwiegereltern sich ankündigen, werden geschwind der seit zwei Monaten tote Zimmerefeu gegossen und die Pestoreste von den Tellern gemeißelt.).

- frame-scenarios of unique situations (Ein ganz neues Geschäftsfeld tut sich auf: Wer in Steueroasen Zugang zu geheimen Bankinformationen hat, kann damit Millionen verdienen. Ein Anruf beim BND genügt. Das ist die eigentliche Lehre aus der Liechtenstein-Affäre.)

4. Frame-installations are cognitive structures that hold estimates of social phenomena, structures or problems (such as the state system of education, nuclear energy or abortion) shared by society (Man wirft der Kirche keine Münzen in den Klingelbeutel, damit sie davon Panzer kauft.).

As a percentage, the four frame groups identified were distributed as follows:

- frame-concepts - $63 \%$;

- frame-scenarios - $18 \%$;

- language frames - $16 \%$;

- frame-installations - $3 \%$.

The type of concept frames is the most numerous. In this case, the percentage distribution of thematic groups of frames within the type is as follows:

- Existential-common frames - 36\%;

- existential-political frames - 27\%;

- frame-personalities - $22 \%$;

- culturological frames - 7\%;

- financial frames - $6 \%$;

- medical frames - $2 \%$.

The next key question is which procedures should be used to create / identify the ironic meaning with these frames.

T.A. Znamenskaya, exploring the cognitive aspect of the comic, says that the basis for the appearance of a humorous effect is "a violation of logic between referential links. The loss of traditional logic is achieved by combining incompatible cognitive schemes in one context" [13]. Interruption in the logical integrity of the thinking process occurs in the work memory section. When received, the information is judged by the quality of the referent 
as familiar and already having a suitable concept in long-term memory. There is an almost automatic request of the necessary concept for a particular referent, and when the reference is found and returned for further processing into working memory, the concept collides with the subsequent 'foreign' referent [14].

In other words, we are talking about cognitive contradiction, the collision of information quanta - available in the archive of memory and offered by the addressee for perception. It is obvious that irony has the same model in the base. It is the violation of reference links that is the basis for the ironic meaning.

It is necessary to clarify that the addressee should be aware of the intentionality of this imbalance, and the addresser must be sure that the addressee recognizes this intentionality. Only the fulfillment of both these conditions allows interpreting the disproportion at the cognitive level as the intention of the addresser to convey an ironic attitude to the reported. The prerequisite for fulfilling all these conditions and, as a result, successful ironic communication is the appeal to those frames and their slots that recipients are guaranteed to have, and the confidence of the recipients that the activated information frames are common both for the recipients and for the sender of the ironic message.

To describe the cognitive model of irony, the model of neutral discourse proposed by O. Yokoyama is applied to the ironic discourse.

1. At the heart of the transactional model of discourse, which is a universal mechanism for explaining the communicative process, lie four sets of knowledge that can move and intersect with the interlocutors (Fig. 1):

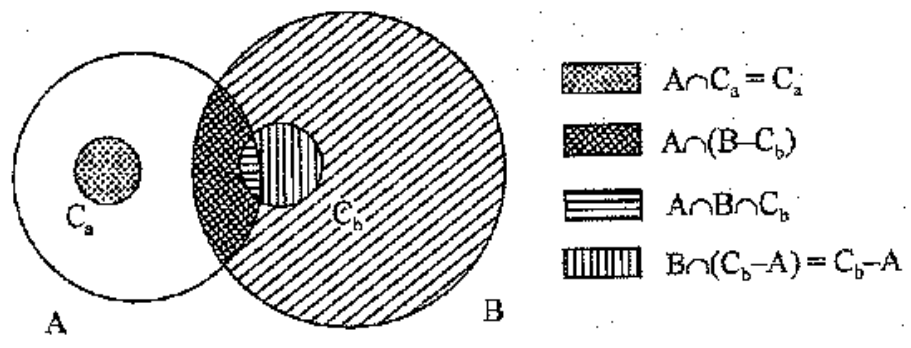

Fig. 1:

A - all the cognitive set of A; B - all the cognitive set of B;

$\mathrm{C}_{\mathrm{a}}$ - active knowledge of $\mathrm{A}$, that is, what $\mathrm{A}$ is thinking about at the moment;

$\mathrm{C}_{\mathrm{b}}$ - active knowledge of $\mathrm{B}$, that is, what $\mathrm{B}$ is thinking about at the moment

In the situation reflected in Figure 1, the subject of actual attention of $A$ is the set $C_{a}$, lying entirely outside $B$ cognitive set. Actualized knowledge of $\mathrm{B}$ ( set of $\mathrm{C}_{\mathrm{b}}$ ) for the most part is unknown to A, although some of this knowledge is available to both people. 
With standard neutral communication, the general model of knowledge transfer looks like this: Speaker A determines the focus of attention, activating the common subset of $\mathrm{A}$ and $\mathrm{B}$ (i.e. puts some knowledge of the field $A \cap B$ into $C_{a} \cap C_{b}$ ), and then sends it to $C_{b}$ knowledge, available in their $\mathrm{AB}$ (i.e., which, by the assumption of Speaker A, did not exist in the set $B$ before the statement).

What happens at the cognitive level in the case of ironic utterance? Here is the simplest example.

Consider the situation when $\mathrm{B}$ drops a valuable vase and breaks it. In this case, the field of actualized knowledge $C_{a} \cap C_{b}$ is determined by the situation itself - in particular, by the sound attracting the attention of both communicants. The situation after the vase falls down can be schematically shown as follows (Fig. 2):

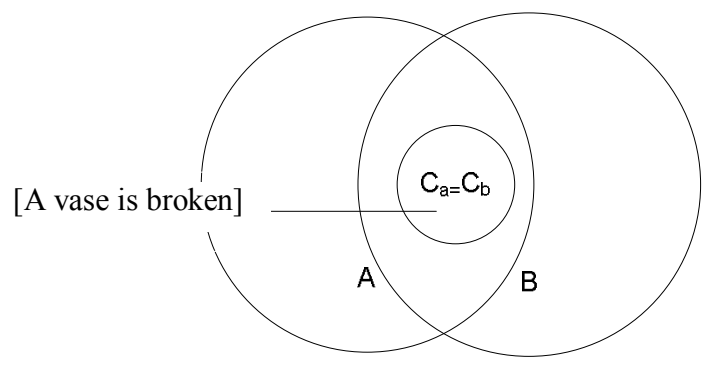

Fig. 2

In this case, $\mathrm{A}$ and $\mathrm{B}$ have a common cognitive subset of $\mathrm{A} \cap \mathrm{B}$ knowledge that causing damage (such as breaking a vase) is a bad event. Accordingly, the initiator of this event misbehaves. Schematically, it is as follows (Fig. 3):

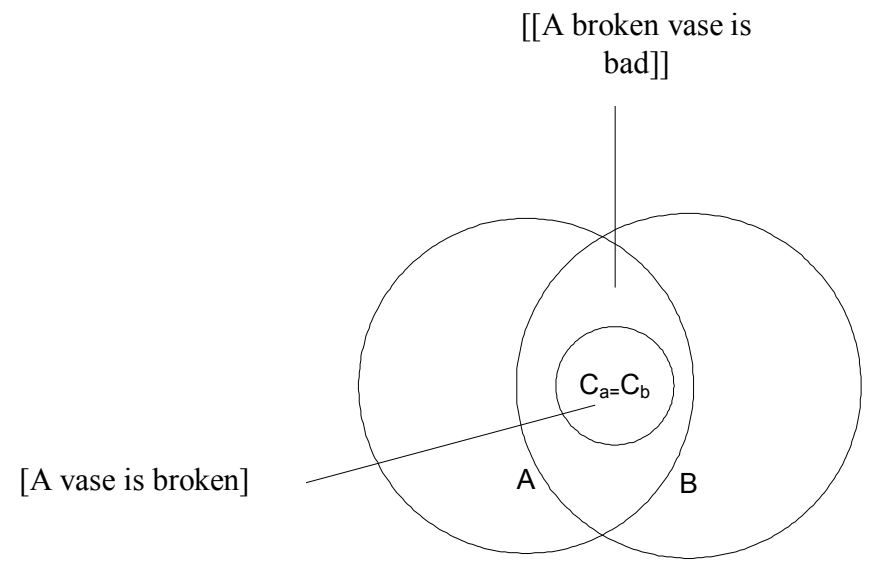

Fig. 3 
After determining the $\mathrm{C}_{\mathrm{a}} \cap \mathrm{C}_{\mathrm{b}}$ area, Speaker $\mathrm{A}$ intends to express criticism, which, in the case of a neutral utterance, they would simply transfer from subset A-B to a subset $\mathrm{C}_{\mathrm{b}}$ (Fig. 4):

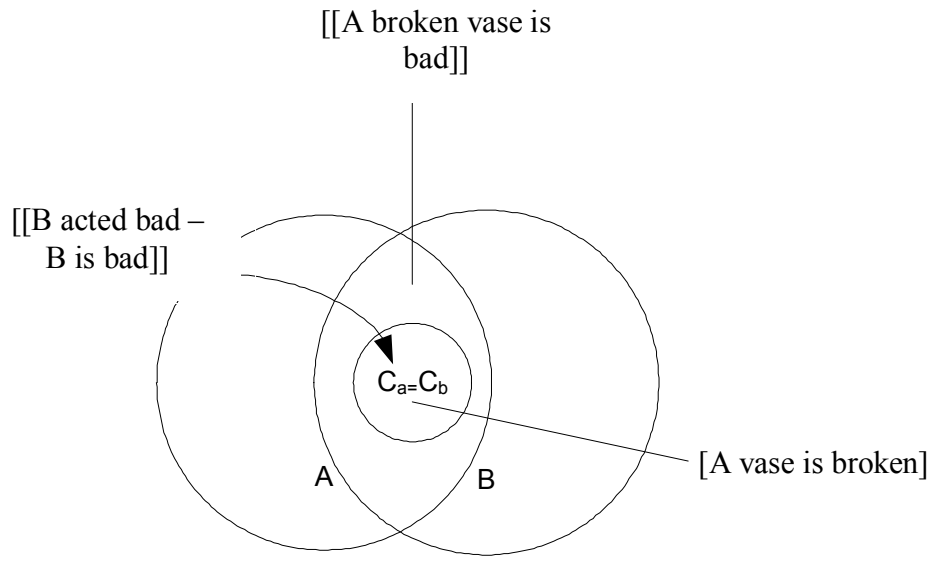

Fig. 4

Now, suppose that A exclaims ironically: "Well, good job!" When using irony, A embodies the concept of criticism as a "praise" frame, expressing it in words "Well, good job!" Similar to the neutral utterance, it transfers this frame from a subset A-B to a subset $\mathrm{C}_{\mathrm{b}}$, but, at the same time, the frame activated by A shouting, "Well, good job!" is superimposed on the existing

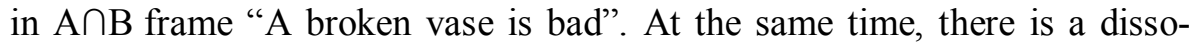
nance which does not allow the frame to be freely received in the area $\mathrm{C}_{\mathrm{a}} \cap \mathrm{C}_{\mathrm{b}}$. The unacceptable combination of frames interprets such utterance as ironic (Fig. 5).

[[A broken vase is bad]]

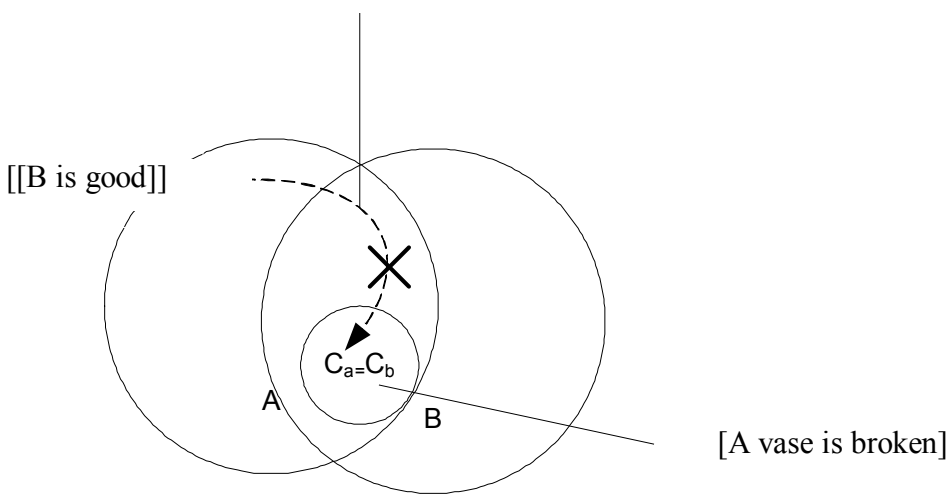

Fig. 5 
So, the frame of A-B area activated by the ironic utterance, according to the transactional model of discourse, will move to $\mathrm{C}_{\mathrm{a}} \cap \mathrm{C}_{\mathrm{b}}$, area, but an unacceptable combination of the 'proposed' activated frame and some of the frames of $\mathrm{C}_{\mathrm{a}} \cap \mathrm{C}_{\mathrm{b}}$ area makes us interpret the utterance as ironic.

Thus, the general model of ironic utterance includes the following stages:

1. Activation of general knowledge (emphasis on cognitive attention to a common object for communicants).

2. Conscious deformation of the true knowledge of the addresser in A$\mathrm{B}$ area (modeling a contradictory cognitive structure, wherein for successful communication the addresser should use the common communicants' frames of $\mathrm{A} \cap \mathrm{B}$ area).

3. Transfer of deformed knowledge from A-B area to $\mathrm{C}_{\mathrm{a}} \cap \mathrm{C}_{\mathrm{b}}$ area.

4. Appearance of a barrier for the transferred frame in $A \cap B$ area due to incompatibility with the information frames of $\mathrm{A} \cap \mathrm{B}$ area.

5. Interpretation of the utterance as ironic by the addressee.

The concept of deformation is the key in this model. By deformation of knowledge, a partial violation of the frame that is obvious for all communication participants and ensures the success of the ironic utterance is meant. For instance, a remark "Ramaphosa war Gewerkschaftskämpfer und Minenboss, was die Süddeutsche fragen lässt: Wer ist er? Und wie viele?" only partially violates the model of neutral discourse, deforming the language frame typical for the norm of using the singular and plural in relation to the same person (M.K. Ramafose is the South African government, political, trade unionists and entrepreneurs).

The peculiarity of the cognitive model of irony in the newspaper is that in the written communication there is not a two-way exchange of frames from the conceptual spheres of speech partners but one-sided replenishment of $\mathrm{C}_{\mathrm{a}} \cap \mathrm{C}_{\mathrm{b}}$ area. Modeling a contradictory cognitive structure, the addresser should use the information from their cognitive map which is for sure available in the cognitive map of the interlocutor. The journalist does not have the opportunity to learn from the preliminary communication whether there is some knowledge in the $\mathrm{A} \cap \mathrm{B}$ area, relying on which they can make the ironic utterances. Therefore, most often they preliminarily mention, in one way or another, the knowledge necessary for them, actualizing it for those who already have it, and transfers it into the sphere of concepts of those who did not have it. In newspapers and magazines, this function is often performed by a subtitle.

So, the key place in the model of the ironic utterance is the conscious deformation of the transferred information. The study of the corpus of examples of irony in the political articles of German-language newspapers and magazines revealed eight basic ways of such deformation, in other words, 8 key linguo-cognitive types of the general model of ironic utterance. 
1. Contradictory characteristic of the frame in the text. In ironic utterances, the deformation of the frame occurs due to attribution to the frame-concept, frame-script or frame-installation of a certain characteristic that contradicts the traditionally established signs of the frame in the minds of communicants (Eine Ukrainerin und ein Franzose werden qua Eistanz Lieblingsdeutsche.).

2. Contradictory comparison of frames. The utterance takes on an ironic color if the logic of the unifying framework of two compared frames is violated (Die Formate "Dschungelcamp" und "SPD-Parteitag" sind beim Thema "Ekelprüfung" kaum noch zu unterscheiden.).

3. Violation of the cause-effect relationship. In the ironic model, there is a conscious deformation of the cause-effect relations between the objects of the surrounding reality, easily restored on a logical basis (Wenn die eigenen Blagen schlechte Noten bekommen, ist es auch eine Idee, die besseren Schüler aus der Klasse zu schmeißen.).

4. Violation of the language norm (code change). This cognitive model concerns only language frames. A code change may be a change in the stylistic register, violation of the internal norm of the text, distortion of the phonetic appearance of words, violation of the laws of word formation, use of foreign words as components of other code, literal interpretation of phraseological unit, etc. (WählerInnen müssen nicht mehr leidermerkeln, sondern können durchnahlen [derived from the names of Angela Merkel and Andrea Nahles]).

5. The assertion of the opposite meaning (antiphrasis). This is one of the antiphrasis types where behind a seemingly strong statement or consent there is an implicit denial or disagreement. Cognitive alogism occurs when, instead of the expected affirmative or positive evaluation, language representatives of a frame rejecting something or containing a negative evaluation of an object, event or fact appear in the sentence. The same alogism is also observed with firm disagreement (verbal or non-verbal), when there is every reason to assume a positive evaluation from the speaker (Es geht uns glänzend, und der Glanz wird ungerecht verteilt.).

6. The illogical contrast between linguistic units expressing the same or similar frames. One way to deform knowledge that has an ironic effect is the illogical contrast between two or more language expressions of the same frame (Merkel dagegen klingt nicht fachmännisch, sie klingt nicht mal fachfrauisch.).

7. Exaggeration of the degree of quality (hyperbole). Increasing the degree of quality to absurd is another way of deforming the transmitted knowledge in order to create an ironic meaning. The greater the increase, the stronger is the effect of using hyperbole (Apropos Neckarufer: Die Stadthalle würde sehr viel mehr Charme versprühen, wenn man sie um 30 Etagen aufstockt und mit einer gläsernen Welle als Dach versieht 
[about Mr. Heidelberg's preparation for the arrival of Prince William and his wife]).

8. Hypertrophic understatement. The way of deformation is the opposite of the previous description: the speaker/writer significantly understates a quality in order to emphasize its insufficiency; the more significant the understatement, the stronger the effect of litotes (Vorher glaubten viele, neben Waffen und Autos verstünden wir auch was von Musik.).

These eight basic linguo-cognitive types of the model of ironic utterances are presented unevenly in German political journalism. Their percentage is shown in the table below:

\begin{tabular}{|l|c|}
\hline \multicolumn{1}{|c|}{$\begin{array}{c}\text { The linguistic cognitive model of realization } \\
\text { of the ironic meaning }\end{array}$} & $\begin{array}{c}\text { The share of examples of } \\
\text { ironic utterances in Ger- } \\
\text { man journalism imple- } \\
\text { menting this model, \% }\end{array}$ \\
\hline Contradictory characteristic of the frame in the text & 39 \\
\hline Contradictory comparison of frames & 18 \\
\hline Violation of the language norm (code change) & 18 \\
\hline Violation of the cause-effect relationship & 3 \\
\hline Exaggeration of the degree of quality (hyperbole) & 2 \\
\hline $\begin{array}{l}\text { Illogical contrast between linguistic units expressing the } \\
\text { same or similar frames }\end{array}$ & 2 \\
\hline Hypertrophic understatement (litotes) & 1 \\
\hline Assertion of the opposite meaning (antiphrasis) & 17 \\
\hline
\end{tabular}

\section{Discussion}

The collected material showed that both linguistic explanations of varying lengths (from one word to a paragraph) and paralinguistic factors (e.g., relevance and increased attention to the situation, fact or person at a specific time) can serve as the context in which the irony of the utterance is realized.

It is important to note that for understanding the irony not one but several types of frames are often relevant. A structural hierarchy of frames is of great importance for the success of an ironic saying. The ease of interpretation of the ironic meaning depends on which nodes of the frame structure vertex or lower level - are verbalized in the utterance.

Another significant feature of the frames is that they can easily be restructured and become part of another frame or be combined with other frames into complex modules. The intersection of frames becomes possible due to the common slot which has the same content for different frames. At the verbal level, the intersection of frames is explicated due to the common linguistic expression of such slot, for example, the Regen lexeme, expressing the common slot 'rain' in the scenario of a major flood in Germany and Im Regen stehen lassen phraseology. 
The linguo-cognitive analysis of examples revealed a certain dependence in the combination of information frames and the type of linguocognitive model.

Thus, in the linguo-cognitive mechanism based on the code change, the language frame is necessarily used as the main one, although the use of other types of information frames in combination with the language type here is also not excluded.

Implementing the type 'contradictory features of a frame in a text', information frames of all types can be involved.

The ironic utterance model containing a violation of the logic of cause-effect relationship requires the activation of at least one frame - scenario, since such violation a priori presupposes some dynamics of events, and this, as noted above, is characteristic only of frame scenarios. In the transformation of the cause-effect relationship in the original frame-scenario, dissonance arises because of the contrast of the real and traditional frames being compared. If the purpose of this unexpected dissonance is to express a critical attitude, then we are talking about an ironic meaning.

It should be noted that this classification of linguo-cognitive types of the model of ironic utterance, as well as classification of information frames, refers exclusively to the material selected from the political articles in German newspapers and magazines. Comparison of the individual results of this work with the study results of the irony in oral colloquial speech showed some differences in the use of individual cognitive schemes. For example, cognitive illogic caused by the replacement of the expected denial of approval and implemented mainly due to the change of the narrator's perspective is the least productive way to develop the ironic utterances in the German news media, while oral communication has large numbers of such examples, as indicated in the study of irony in colloquial speech by M. Hartung [15: 196]. Probably, in other languages and other functional styles of the German language, the list of types for the cognitive model of ironic utterances, as well as their quantitative correlation, may be different.

The linguo-cognitive analysis of ironic utterances in all the eight types allows drawing an important conclusion about the dual role of language in such utterances.

In the vast majority of examples, language frames serve as an explication of frame-concepts, -scripts and -installations on which irony is focused. Language in these cases is necessary for verbal transmission to the reader of the violation of the logic of referential links between or within frames of a non-linguistic type.

Such an indirect way of participating in ironic communication is different from the direct role of language frames in creating an ironic meaning [16-42]. As a direct source of ironic meaning, language frames appear when the use of a word in the newspaper language that contradicts its semantic, 
stylistic and connotative marking, and deviation from the norms of lexical and syntactic compatibility results in a language game consisting in a conscious change in the code, in violation of the linguistic norms, in 'deviation from stereotypes'.

In this role, the language appears only in one of the identified linguocognitive model types for the ironic utterance, namely in the "Violation of the language norm (code change)' type.

Sometimes, there is a combination of both functions of language frames, that is, the violation of the language norm is in itself a triggering mechanism of ironic meaning, and the concept, script or installation explicated using this language frame also carries a violation of the logic of referential connections between or within frames of a non-linguistic type, which creates an additional ironic meaning. Der kostenlose Nahverkehr sei unbezahlbar, schimpfen die Kommunen. Auch sonst wird an der Idee kaum ein gutes Haar gelassen. Ist sie wirklich so schlecht? - Für gutes Haar sehe ich mich als Experten. The irony of the answer of the well-known columnist Friedrich Küppersbusch in this example has two sources, which makes the ironic effect particularly strong. Firstly, the reference to the literal meaning of the word gutes Haar instead of the associated value of the expression 'kein gutes Haar an etw. Lassen' is perceived as a conscious deformation of the language frame and is interpreted as ironic. Second, at the language level expressed by the proposal of Für gutes Haar sehe ich mich als Experten, the common frame-concept 'expert in good hair' is violated due to a photo of the author of the column, which shows that Mr. Küppersbush is practically bald. Thus, the duality of the function of the language frame generates a double ironic meaning in this example.

\section{Conclusion}

The result of this study was the compilation of the paradigm of information frames and linguo-cognitive models of irony based on the German political journalism. In terms of further study prospects, several areas can be identified.

Quite interesting is the linguocognitive study of irony in the German tabloid texts and the identification of the paradigm of the linguocognitive types of the model of ironic utterances, characteristic of this genre, with a subsequent comparison of the conclusions with the results of the present study.

In addition, it is certainly promising to study the linguo-cognitive side of ironic utterances in the texts of other styles and genres: in colloquial speech, in literary texts, etc.

In conclusion, it should be noted that all the classifications and models presented in the study, like any attempt to more or less hierarchize the phe- 
nomena of language and speech, are 'artificial' to a certain extent, because one has to break a single, integral, living organism into its constituent parts. Nevertheless, the results obtained make it possible to say that even such 'human' manifestations as, in particular, irony, are subject to systematization and description, which in the future can be used in the artificial intelligence technologies.

According to A. Kibrik's fair remarks, the mechanisms of the brain, thinking, consciousness and language become the most important center of interest in the science of the coming century. The present study is a small step in creating a portrait of the 'most complex scientific object that exists in the universe' - a person.

Information about the author:

Kotiurova I.A. - Candidate of Philological Sciences, Head of the Department of German and French, Institute of foreign languages, Petrozavodsk State University (Petrozavodsk, Russia). E-mail:koturova@petrsu.ru,koturova@gmail.com

\section{References}

1. Kotyurova, I.A.: Concepts of irony in foreign linguistics (overview of the main theoretical approaches) // Achievements in the university science, 1. Penza. 141-145 (2018)

2. Akhmanova, O.S.: Dictionary of Linguistic Terms. M. (1966)

3. Lewandowski, T.: Linguistisches Wörterbuch, Bd.2. Stuttgart (2004)

4. Kibrik, A.A.: Cognitive research on discourse // Issues of Linguistics, 5. M., 126-139 (1994)

5. Sapir, E.: Language. Introduction to the study of speech. // Selected works on Linguistics and Culturology. M. (1993)

6. Brief Dictionary of Cognitive Terms. M. 187-188 (1996)

7. Fillmore, Ch.: Frames and semantics of understanding // New in foreign linguistics. M., 1988. Issue XXIII. 52-92 (2015)

8. Dyke, T.A. Van.: Language. Cognition. Communication. M.: Progress (1989)

9. Minsky, M.: Frames for knowledge representation. M.: Energy (1977)

10. Minsky, M.: Theory of Neural-Analog Reinforcement Systems and Its Application to the Brain Model Problem (PhD thesis). Princeton University (1954)

11. Krasnykh, V.V.: Communicative act and its structure // Functional studies: A collection of articles on Linguistics, 4. M. 43-44

12. Dijk, Teun A. Van: Discourse and Knowledge. A sociocognitive approach. Cambridge: Cambridge University Press (2014)

13. Znamenskaya, T.A.: Grammar humor: violation of referential relations as a basis for the comic // Actual problems of linguistics: Ural linguistic reading, 17. Yekaterinburg (2004)

14. Znamenskaya, T.A.: Dissociation of reference relations as a basis for comic effect // Comparative Linguistics: Bulletin of the Institute of Foreign Languages, 3. Yekaterinburg (2004)

15. Hartung, M.: Ironie in der Alltagssprache. Eine gesprächsanalytische Untersuchung. Verlag für Gesprächsforschung (2002)

16. Amante, D.J.: The Theory of Ironic Speech Acts // Poetics Today, Vol. 2. Tel Aviv. 77-96 (1981)

17. Boldyrev, N.N.: Cognitive semantics / Tambov: Tamb. University (2000)

18. Clyne, M.: Einige Überlegungen zu einer Linguistik der Ironie // ZS für Deutsche Philologie, 93 (1974) 
19. Dementev, V.V.: Irony as a system of communicative intentions // Issues of the theory and practice of studying Russian language, 1. M.; Penza. 69-79 (1998)

20. Demyankov, V.Z.: Cognitive linguistics as a variety of interpretive approach // Issues of Linguistics, 4. M. (1994)

21. Demyankov, V.Z., Zharova D.V., Sergeev A.I.: Contrastive Linguistic Psychology and Psycholinguistics // Issues of Psycholinguistics. M.: Institute of Linguistics of RAS, Moscow Institute of Linguistics, 2 (24). 55-63 (2015)

22. Dijk, Teun A. Van: Communicating Ideologies. Multidisciplinary Perspectives on Language, Discourse and Social Practice. With Martin Pütz and JoAnne Neff-van Aertselaer. Frankfurt / Main: Peter Lang (2004)

23. Gibbs, R.W., O'Brien, J.: Psychological Aspects of Irony Understanding // Journal of Pragmatics, 16. North-Holland. 523-530 (1991)

24. Gießmann, U.: Ironie in sprachwissenschaftlicher Sicht // Sprachwissenschaft, 2 (1977)

25. Grice, H.P.: Logik und Konversation // Handlung, Kommunikation, Bedeutung. Frankfurt / M., 243-265 (1979)

26. Groeben, N., Scheele, B.: Produktion und Rezeption von Ironie. Pragmalinguistische Beschreibung und psycholinguistische Erklärungshypothesen. Tübingen: Narr (1984)

27. Havekate, H.: A Speech Act Analysis of Irony // Journal of Pragmatics, 14 (1990)

28. Kotyurova, I.A.: Various interpretations of the concept of 'irony' in diachronic aspect // European Scientific Conference, Vol. 3. Penza. 25-29 (2017)

29. Krasnykh, V.V.: Fundamentals of Psycholinguistics and Communication Theory. M.: Gnosis (2001)

30. Kreuz, R.J., Glücksberg, S.: How to be sarcastic: The echoic reminder theory of verbal irony // Journal of Experimental Psychology General, Vol. 118 (4) (1989)

31. Kubryakova, E.S.: About Cognitive Linguistics and semantics of the term 'cognitive' // Bulletin of VSU, Linguistics and Intercultural Communication Series. M., 4-10 (2001)

32. Kubryakova, E.S.: Language and knowledge: On the way of getting knowledge about the language: Parts of speech from the cognitive point of view: The role of language in the knowledge of the world. M.: Languages of Slavic culture (2004)

33. Kubryakova, E.S.: Semantics in cognitive linguistics (on the container's concept and the forms of its objectification in the language) // Bulletin of AN. Ser. of lit. and lang, Vol. $58,3-12(1999)$

34. Lakoff, G., Johnson, M.: Metaphors We Live By. University of Chicago Press (1980)

35. Lapp, E.: Linguistik der Ironie. Tübingen: Narr (1992)

36. Löffler, H.: Die sprachliche Ironie Ein Problem der pragmatischen Textanalyse // Eutsche Sprache (1975)

37. Oomen, U.: Ironische Äußerungen Syntax, Semantik, Pragmatik. // ZS für germanistische Linguistik 11 (1983)

38. Rosengren, I.: Ironie als sprachliche Handlung // Sprachnormen in der Diskussion. Berlin: de Gruyter (1986)

39. Sperber, D., Wilson, D.: Irony and the Usemention Distioncion // Radical Pragmatics. New York (1981)

40. Stempel, W.D.: Ironie als Sprechhandlung // Das Komische. München: Fink (1984)

41. Weinrich, H.: Linguistik der Lüge. Heidelberg: Schneider (1966)

42. Yokoyama, O.B.: Cognitive model of discourse and Russian word order. M.: Languages of Slavic culture (2005) 